\title{
Acute Effects of Vitamin C Exposure On Colonic Crypts: Direct Modulation of pH Regulation
}

\author{
Mohammed M. Aldajani ${ }^{a} \quad$ Clemens N. Vaniceka,b Norah Alhazzaaa ${ }^{a, c} \quad$ Taras Lysyy ${ }^{a}$ \\ Raghav Agarwala John P. Geibel ${ }^{a}$ \\ aYale University, School of Medicine, Department of Surgery, New Haven, CT, USA; 'Paracelsus Medical \\ University, Salzburg, Austria; 'Alfaisal University, School of Medicine, Riyadh, Saudi Arabia
}

\section{Key Words}

Intestines $\bullet$ Malignancies $\bullet \mathrm{PH} \bullet$ Fluid Movement $\bullet$ Rats $\bullet$ Nutraceutical $•$ Tumors

\begin{abstract}
Background/Aim: Colorectal cancer is still considered a leading cause of death in the United States and worldwide. One potential way to improve survival besides detection is to look to new therapeutic agents that can be taken prophylactically to reduce the risk of tumor formation. For cancer cells to grow and invade, a higher (more alkaline) intracellular pH must occur. We chose to examine a specific nutraceutical agent, which is Vitamin C. The acute effect of Vitamin $C$ exposure on normal colonic crypts has been studied, providing some insight into how Vitamin $\mathrm{C}$ achieve its effect. Methods: Distal colon was excised from rats. Following enzymatic digestion single colonic crypts were isolated. Colonic crypts were loaded with $\mathrm{pH}$ sensitive dye to measure the intracellular $\mathrm{pH}$ changes. Crypts were exposed to solutions +/Vitamin C. Results: $10 \mathrm{mM}$ Vitamin $\mathrm{C}$ decreased $\mathrm{Na}^{+}$-dependent intracellular pH recovery. Vitamin C modulates SVCT leading to changes in proton extrusion. Vitamin C entry occurs via either SVCT2 on the basolateral membrane or by transcellular passive diffusion through tight junctions to the apical membrane and then active transport via SVCT1. Conclusion: Acute addition of Vitamin $\mathrm{C}$ to the basolateral membrane maintains low intracellular $\mathrm{pH}$ for a longer period which could halt and/or prevent tumor formation.

(C) 2017 The Author(s)

Published by S. Karger AG, Basel
\end{abstract}

\section{Introduction}

Colorectal cancer is the third most common cancer worldwide and the third most common cause of death with just over one hundred thousand new cases diagnosed each year equally divided between men and women [1]. The United States has among one of the highest levels for all countries and has approximately 93, 000 diagnosed cases per year, and an estimated death rate of 49,000 per year [2]. 


\section{Cellular Physiology Cell Physiol Biochem 2017;44:377-387 \begin{tabular}{l|l} 
and Biochemistry Published on/ne: November 13, 2017 & $\begin{array}{l}\text { C) } 2017 \text { The Author(s). Published by S. Karger AG, Basel } \\
\text { www.karger.com/cpb }\end{array}$ \\
\hline POI
\end{tabular} \\ Aldajani et al.: Vitamin C- Dependent Ph Changes in Crypts}

One of the common pathophysiological pathways for cancer to grow, proliferate and invade neighboring cells, is that the cancer cell must maintain an elevated intracellular $\mathrm{pH}$ $\left(\mathrm{pH}_{\mathrm{i}}\right)$ and concurrently a significantly lower $\mathrm{pH}$ of the extracellular environment $\left(\mathrm{pH}_{\mathrm{e}}\right)[3,4]$. By understanding the intracellular ionic signaling pathways, it may be possible to manipulate the $\mathrm{pH}_{\mathrm{i}}$ of a cancer cell thereby arresting its growth. Similarly, modulating the $\mathrm{pH}_{\mathrm{e}}$ may prevent or retard the growth of the tumor. The modulation of these two environments $\left(\mathrm{pH}_{\mathrm{i}}\right.$ and $\left.\mathrm{pH}_{\mathrm{e}}\right)$ via targeting the specific ionic exchange proteins could thus be a promising novel treatment strategy. Vitamin C (Ascorbic Acid) is known to play a role in the differentiation process of cells [5], showing that Vitamin $\mathrm{C}$ has capabilities to modulate cells proliferation, which suggests a possible inhibitory action also on tumor cells [6]. As an antitumorigenic, Vitamin $\mathrm{C}$ has been proven to protect against several types of non-hormonal cancers in lung and colon [7-9]. Maulén et al. showed that the analysis of quantitative PCR of colonic carcinoma cell line, which revealed that the expression of the Na-dependent Vitamin C transporters SVCT 1 mRNA increased by 4 fold without changes in SVCT2 mRNA levels. Moreover, this study also showed that the Vmax increased also by at least 2-fold [10].

Recent studies have shown that Vitamin $\mathrm{C}$ is absorbed throughout the intestine via an energy-dependent Na-dependent process that is saturable. In previous studies, this absorption of Vitamin C was associated with Glucose transport $[11,12]$. If this relationship to Na-dependent Glucose transport can be exploited, it may be possible to enhance the uptake of Vitamin C and thus further provide an antitumorigenic effect [13]. Under these conditions, we would expect an enhanced modulation of the $\mathrm{pH}$-dependent processes both intracellularly and extracellularly. Our studies presented below also focused on the uptake of Vitamin C via SVCT1 and SVCT2 [14-16], and glucose Transporters (GLUT) and their effects on acid extrusion or uptake. We further examined the concentration dependence of these effects by using 3 concentrations that were either 10 -fold lower or higher than the suggested maximal daily dose [17]. The highest concentration used in this study was comparable to a dose used clinically in attempting to reduce tumor growth [18]. In the present study, we chose to investigate the physiological process(es) that occurs in an acute exposure of Vitamin C on normal colonic crypts and to determine if there are any modulations in sodium dependent hydrogen ion extrusion.

\section{Materials and Methods}

\section{Animals}

Male Sprague-Dawley rats weighing 300-650g were used in this study. All animals were kept in a climate controlled facility. The animals were fed standard chow and had ad lib access to water prior to experimentation. The animals were handled by animal care personnel according to the approved protocol by The Institutional Animal Care and Use Committee at Yale University (protocol number 2015-10253). The animals were fasted for 12 hours before tissue harvest with ad lib access to water during this period [19].

\section{Colonic Crypt Isolation and Collection}

All animals used in the study were exposed to an overdose of the inhaled anesthetic Isoflurane. We then performed a laparotomy to expose the colon and excise it. We identified the anal junction and made a transverse dissection. We then removed $\sim 10 \mathrm{~cm}$ proximal to the anal colon junctional interface. The colon was then removed and flushed with $4^{\circ} \mathrm{C}$ cold HEPES Ringer solution (See Table 1) to remove the residual fecal material from the interior of the colon as previously described [20]. Briefly, we cut the clean distal colon into two longitudinal strips $[21,22]$. The two strips were then immersed into a digestion solution that was composed of a low Calcium High EDTA/HEPES buffer. Following digestion, the colon was removed and discarded, and the remaining solution was centrifuged at $500 \mathrm{rpm}$ for 45 seconds. Using our previously described technique, we then removed the digestion buffer and rehydrated the remaining pallet with a cold HEPES pH 7.4 at $4^{\circ} \mathrm{C}$ (see Table 1 ) [23]. 


\section{Cellular Physiology Cell Physiol Biochem 2017;44:377-387 \begin{tabular}{l|l|l} 
DOI: 10.1159/000484914 & O 2017 The Author(s). Published by S. Karger AG, Basel \\
wwww.karger.com/cpb
\end{tabular} \\ Aldajani et al.: Vitamin C- Dependent Ph Changes in Crypts}

Table 1. Composition of Solutions. All solutions were adjusted to a final osmolality of $300 \mathrm{mOsm}$ at $\mathrm{pH} 7.4$ at $37^{\circ} \mathrm{C}$

\begin{tabular}{|c|c|c|}
\hline Solution & Composition in $\mathrm{mM}$ & $\mathrm{pH}$ \\
\hline Standard $\mathrm{Na}^{+}$Concentration & $\mathrm{NaCl}(117), \mathrm{KCl}(5), \mathrm{CaCl}_{2} * 2 \mathrm{H}_{2} \mathrm{O}(1), \mathrm{MgSO}_{4} * 7 \mathrm{H}_{2} \mathrm{O}$ (1.2), $\mathrm{HEPES}(32.2)$, & 7.4 at \\
\hline HEPES $(117 \mathrm{mM})$ & Glucose (10). & $37^{\circ} \mathrm{C}$ \\
\hline Low $\mathrm{Na}^{+}$Concentration & $\mathrm{NaCl}(77), \mathrm{KCl}(5), \mathrm{CaCl}_{2} * 2 \mathrm{H}_{2} \mathrm{O}(1), \mathrm{MgSO}_{4} * 7 \mathrm{H}_{2} \mathrm{O}(1.2)$, HEPES (32.2), Glucose & 7.4 at \\
\hline HEPES (77 mM Na) & (10), NMDG (40) & $37^{\circ} \mathrm{C}$ \\
\hline $\begin{array}{l}\text { Glucose-Free HEPES }(117 \\
\mathrm{mM})\end{array}$ & $\mathrm{NaCl}(117), \mathrm{KCl}(5), \mathrm{CaCl}_{2} * 2 \mathrm{H}_{2} \mathrm{O}(1), \mathrm{MgSO}_{4} * 7 \mathrm{H}_{2} \mathrm{O}(1.2)$, $\mathrm{HEPES}(32.2)$. & $\begin{array}{l}7.4 \text { at } \\
37^{\circ} \mathrm{C}\end{array}$ \\
\hline Cold HEPES & $\begin{array}{l}\mathrm{NaCl}(117), \mathrm{KCl}(5), \mathrm{CaCl}_{2} * 2 \mathrm{H}_{2} \mathrm{O}(1), \mathrm{MgSO}_{4} * 7 \mathrm{H}_{2} \mathrm{O}(1.2), \mathrm{HEPES}(32.2), \\
\text { Glucose (10) }\end{array}$ & $\begin{array}{c}7.4 \text { at } \\
5{ }^{\circ} \mathrm{C}\end{array}$ \\
\hline Room temperature HEPES & $\begin{array}{l}\mathrm{NaCl} \text { (117), } \mathrm{KCl}(5), \mathrm{CaCl}_{2} * 2 \mathrm{H}_{2} \mathrm{O}(1), \mathrm{MgSO}_{4} * 7 \mathrm{H}_{2} \mathrm{O}(1.2), \operatorname{HEPES}(32.2), \\
\text { Glucose (10) }\end{array}$ & $\begin{array}{l}7.4 \text { at } \\
20^{\circ} \mathrm{C}\end{array}$ \\
\hline $\mathrm{NH} 4 \mathrm{Cl}$ & $\begin{array}{c}\mathrm{NaCl}(77), \mathrm{NH}_{4} \mathrm{Cl}(40), \mathrm{KCl}(5), \mathrm{CaCl}_{2} * 2 \mathrm{H}_{2} \mathrm{O}(1), \mathrm{MgSO}_{4} * 7 \mathrm{H}_{2} \mathrm{O}(1.2), \text { HEPES } \\
\text { (32.2), Glucose (10). }\end{array}$ & $\begin{array}{l}7.4 \text { at } \\
37^{\circ} \mathrm{C}\end{array}$ \\
\hline Glucose-Free & $\mathrm{NaCl}(77), \mathrm{NH}_{4} \mathrm{Cl}(40), \mathrm{KCl}(5), \mathrm{CaCl}_{2} * 2 \mathrm{H}_{2} \mathrm{O}$ (1), $\mathrm{MgSO}_{4} * 7 \mathrm{H}_{2} \mathrm{O}$ (1.2), HEPES & 7.4 at \\
\hline $\mathrm{NH} 4 \mathrm{Cl}$ & $(32.2)$ & $37^{\circ} \mathrm{C}$ \\
\hline$\varnothing \mathrm{Na}^{+}$ & $\begin{array}{l}\text { NMDG (N-Methylglucamine; 1-Deoxy-1-(methylamino)-D-glucitol) (132.8), } \\
\qquad \mathrm{KCl}(5), \mathrm{CaCl}_{2} * 2 \mathrm{H}_{2} \mathrm{O} \text { (1), } \mathrm{MgSO}_{4} * 7 \mathrm{H}_{2} \mathrm{O}(1.2), \mathrm{HEPES} \text { (32.2), Glucose (10) }\end{array}$ & $\begin{array}{l}7.4 \text { at } \\
37^{\circ} \mathrm{C}\end{array}$ \\
\hline Glucose-Free & NMDG (N-Methylglucamine; 1-Deoxy-1-(methylamino)-D-glucitol) (132.8), & 7.4 at \\
\hline$\varnothing \mathrm{Na}^{+}$ & $\mathrm{KCl}(5), \mathrm{CaCl}_{2} * 2 \mathrm{H}_{2} \mathrm{O}(1), \mathrm{MgSO}_{4} * 7 \mathrm{H}_{2} \mathrm{O}(1.2), \operatorname{HEPES}(32.2)$ & $37^{\circ} \mathrm{C}$ \\
\hline High-K & $\begin{array}{c}\mathrm{KCl}(105), \mathrm{CaCl}_{2} * 2 \mathrm{H}_{2} \mathrm{O}(1), \mathrm{MgSO}_{4} * 7 \mathrm{H}_{2} \mathrm{O}(1.2), \mathrm{HEPES}(32.2), \mathrm{NMDG}(32.8), \\
\text { Mannitol (5) }\end{array}$ & $\begin{array}{l}7.0 \text { at } \\
37^{\circ} \mathrm{C}\end{array}$ \\
\hline
\end{tabular}

Dye preparation and cell loading

A coverslip (Fisherbrand $\AA$, Fisher Scientific measuring 22 × $50 \mathrm{~mm}$ ) pretreated with $0.1 \mu \mathrm{L}$ of Corning $®$ Cell-Tak ${ }^{\mathrm{TM}}$ (Cell and Tissue Adhesive, Polyphenolic proteins secreted by Mytilus edulis). We then transfer a $200 \mu \mathrm{L}$ aliquot of the crypts HEPES solution to the chamber, then incubated the crypts with a $1 \mu \mathrm{L}$ of BCECF/AM dye (Santa Cruz Biotechnology) a pH sensitive dye as previously described [22, 24].

\section{Data collection}

For each BCECF loaded crypt, 5 regions (1 control region and 4 experimental regions) were selected to monitor $\mathrm{pH}_{\mathrm{i}}$ changes for a duration of a single experiment. The crypts were treated with standard HEPES buffer solution, alkalinized it with $\mathrm{NH}_{4} \mathrm{Cl}$, then acidified it by depleting the crypt from $\mathrm{Na}^{+}$through $\emptyset \mathrm{Na}$ perfusion, a reperfusion of the crypts with standard HEPES before lastly calibrated it with High-K/Nigericin. The $\mathrm{pH}_{\mathrm{i}}$ monitored through measuring the average rate of Hydrogen ion extrusion through experiment cycle. The BCECF loaded crypts were excited at 490 and $440 \mathrm{~nm} \pm 20 \mathrm{~nm}$ respectively while collecting the emission at $530 \mathrm{~nm} \pm 20 \mathrm{~nm}$ every $15 \mathrm{~s}$. The $\mathrm{pH}$ was calculated using the High-K/Nigericin calibration technique [22] previously used in our laboratory.

\section{Addition of Vitamin $C$ and other drugs}

L-Ascorbic acid (C6H806) (CAS Number: 50-81-7) and Phlorizin Hydrate: CAS Number : 60-81-1 C21H24010·xH2O were purchased from Sigma-Aldrich Co. (St Louis, MO USA).

Statistics

All data were analyzed with Prism 6 program from GraphPad using Students T- test, when comparing 1 condition to 1 other condition and ANOVA when all columns were compared together. Significance was recorded for each series under all conditions. 
Fig. 1. Measurements of intracellular $\mathrm{pH}$ in isolated rat colonic crypts. Panel $\mathrm{A}$ and $\mathrm{C}$, Isolated crypt loaded with the $\mathrm{pH}$ sensitive dye BCECF. Panel B Original tracing showing the rate of recovery from an acid load in control conditions. Panel D tracing from crypt following exposure to $10 \mathrm{mM}$ Vitamin C. Please note the suppressed Na-dependent $\mathrm{pH}$ recovery following Vitamin C exposure.Key: $\mathrm{C}=$ Control (Standard HEPES), $\mathrm{NH}=\mathrm{NH} 4 \mathrm{Cl}, \mathrm{HK}=$ High-K.

\section{Results}

Vitamin C Concentration Curve

To develop a concentration curve for Vitamin Ceffect(see Fig. 1 and 3 ), different concentrations have been chosen according to previous studies. The pharmacokinetics of Vitamin C show that the body has a tight control keeping the level of Vitamin $C \sim 100$ $\mu \mathrm{M}$ [18]. The maximum tolerable concentration of Vitamin $\mathrm{C}$ has been reported to be around $1 \mathrm{mM}$, while it is proven that a concentration of $10 \mathrm{mM}$ Vitamin C could kill and fight cancer in vitro and in vivo [18]. First, we compared the recovery rate of $\mathrm{pH}_{\mathrm{i}}$ among control experiments $(\Delta \mathrm{pHi} / \mathrm{min} \quad 0.0160)$ and experiments containing 100 $\mu \mathrm{M}$ of vitamin $\mathrm{C}(\Delta \mathrm{pHi} / \mathrm{min}$ $0.0284)$; the recovery rates were faster when we added $100 \mu \mathrm{M}$ of Vitamin C with a $\mathrm{p}$ value of $<0.0001$. On another set of experiments, we increased the concentration of Vitamin $\mathrm{C}$ to $1 \mathrm{mM}$ which is the same as the daily maximum dose [17]; we found that the recovery rate of $\mathrm{pH}_{\mathrm{i}}(\Delta \mathrm{pHi} / \mathrm{min} 0.0203)$
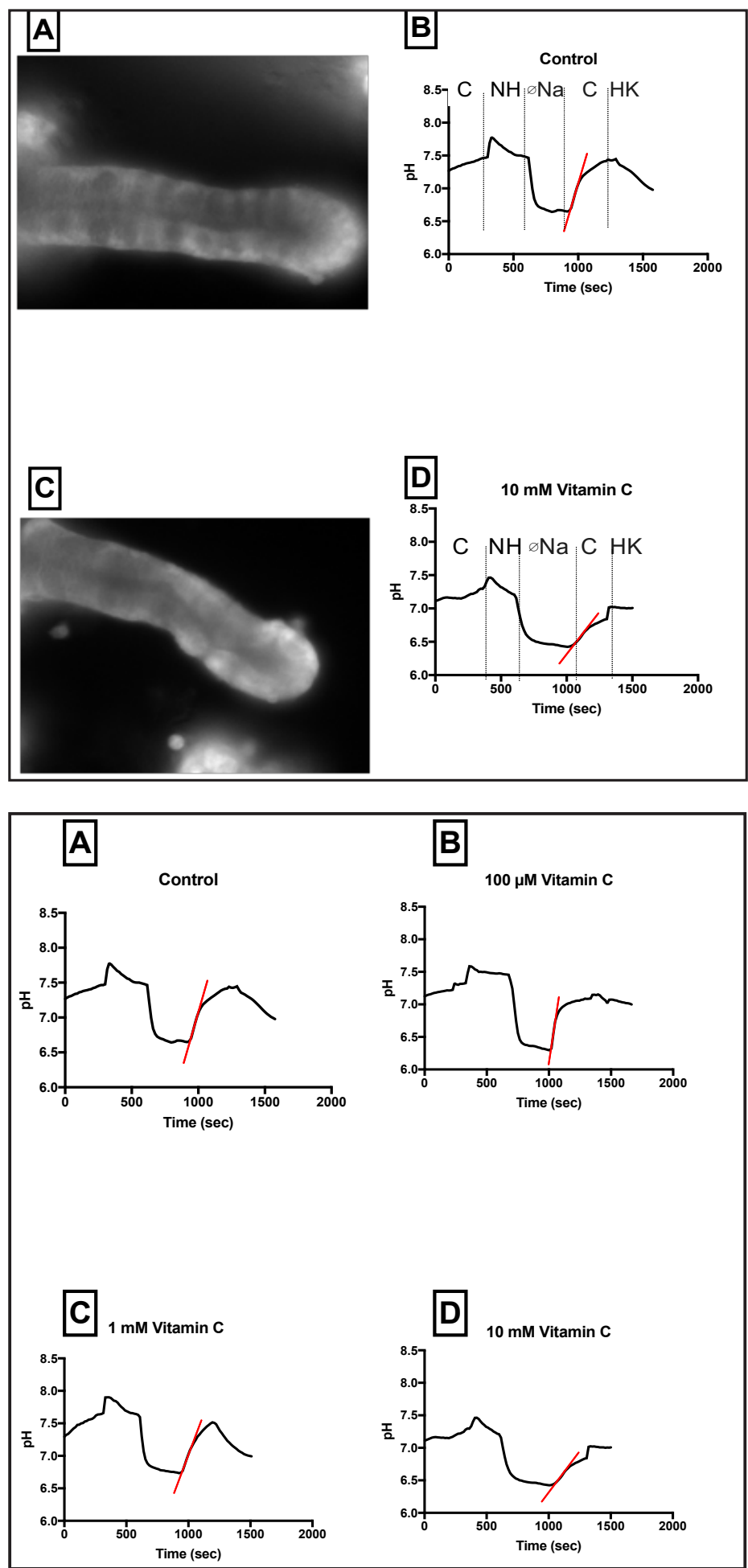

Fig. 2. Tracings showing the recovery rate of intracellular $\mathrm{pH}$ in isolated rat colonic crypts from an acid load in different conditions. Panel A tracing from crypt in control conditions. Panel B tracing from crypt following exposure to $100 \mu \mathrm{M}$ Vitamin C. Panel C tracing from crypt following exposure to $1 \mathrm{mM}$ Vitamin C. Panel D tracing from crypt following exposure to $10 \mathrm{mM}$ Vitamin C. Please note the suppressed Na-dependent $\mathrm{pH}$ recovery following Vitamin C exposure. 
still faster in comparison to control experiments with $\mathrm{p}$ value of $<0.0001$ but slower than that of $100 \mu \mathrm{M}$ with a $p$ value of $<0.0001$. However, when we further increase the concentration of Vitamin C to $10 \mathrm{mM}$, a concentration proposed to kill cancer cells, we found that the $\mathrm{pH}_{\mathrm{i}}$ recovery rate slowed down $(\Delta \mathrm{pHi} / \mathrm{min} 0.0080)$ in comparison to control with a $\mathrm{p}$ value of $<0.0001$. If we compare the $\mathrm{pH}_{\mathrm{i}}$ recovery rate between $100 \mu \mathrm{M}$ of Vitamin $\mathrm{C}$ and $1 \mathrm{mM}$ and $10 \mathrm{mM}$, we observed that $100 \mu \mathrm{M}$ has the fastest recovery with $p$ value of $<0.0001$. Conversely, the recovery rate of $10 \mathrm{mM}$ of Vitamin C is slower than $100 \mu \mathrm{M}$ and $1 \mathrm{mM}$ with $\mathrm{p}$ value of $<0.0001$. Tracings of $\mathrm{pH}_{\mathrm{i}}$ recovery rates are shown in Fig. 2 and the summary data shown in Fig. 3.

SVCT (Sodium Vitamin C Transporter) Role in Vitamin C-Dependent $p H$ modification

To observe and establish a role of SVCT in Vitamin C-dependent $\mathrm{pH}$ modification and how it could modulate the efficacy of Vitamin $\mathrm{C}$ at different concentrations, we designed experiments with the same components of the solutions as found in Table1 except for reducing the $\mathrm{Na}^{+}$concentration to $77 \mathrm{mM}$ (see Fig. 5). Comparing control experiments of standard $\mathrm{Na}^{+}$concentration $(117$ $\mathrm{mM}$ ) with control experiments of 77 $\mathrm{mM} \mathrm{Na}^{+}$concentration, there was no significance difference in the recovery rate of $\mathrm{pHi}$, the $\Delta \mathrm{pHi} / \mathrm{min}$ for 77 $\mathrm{mM} \mathrm{Na}{ }^{+}$was 0.0169 and 0.0160 for the $117 \mathrm{mM} \mathrm{Na}^{+}$respectively. The recovery rate of $\mathrm{pH}_{\mathrm{i}}$ with $100 \mu \mathrm{M}$ of Vitamin C dissolved in $77 \mathrm{mM}$ solution $(\Delta \mathrm{pHi} / \mathrm{min} 0.0098)$ is slower than the control experiments of the same $\mathrm{Na}^{+}$concentration $(77 \mathrm{mM})$ with a $\mathrm{p}$ value of $<0.0001$. However, when we increased the concentration of Vitamin C to $1 \mathrm{mM}$ in the same $77 \mathrm{mM} \mathrm{Na}^{+}$ concentration condition we observed a slower rate of $\mathrm{pH}_{\mathrm{i}}$ recovery $(\Delta \mathrm{pHi} /$ min 0.0128 ) compared to $77 \mathrm{mM} \mathrm{Na}^{+}$ control rates with a p value of 0.0021 . Interestingly, when we increased the

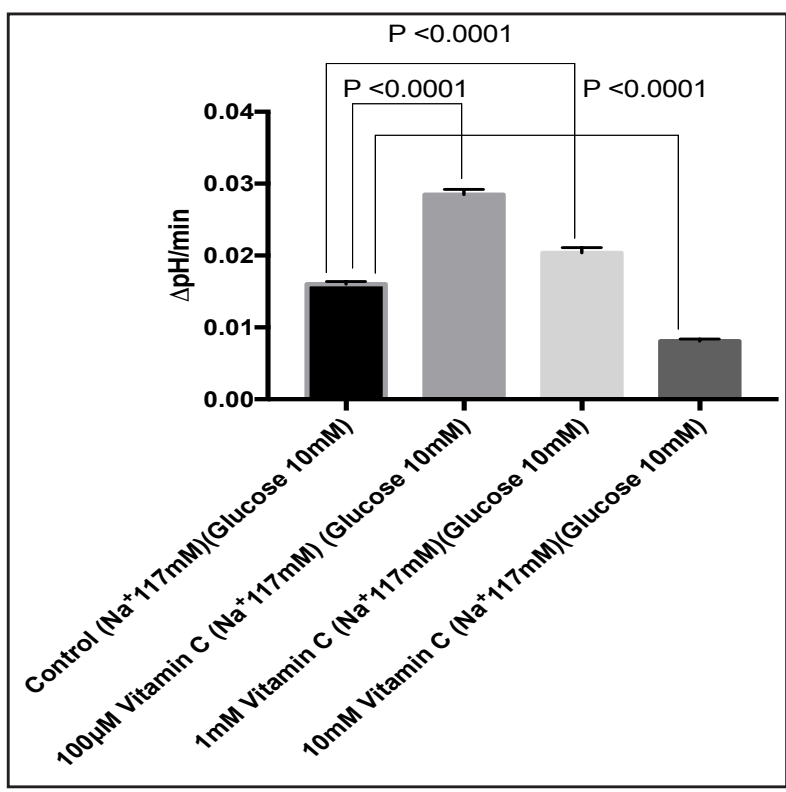

Fig. 3. Vitamin C Concentration Curve. Crypts perfused with $100 \mu \mathrm{M}, 1 \mathrm{mM}$ and $10 \mathrm{mM}$. Please note the slow recovery rate of $\mathrm{pH}$ with $10 \mathrm{mM}$ in comparison with control experiments. The slower rate of $\mathrm{pH}$ recovery become faster with lower doses of Vitamin. $n=40$.

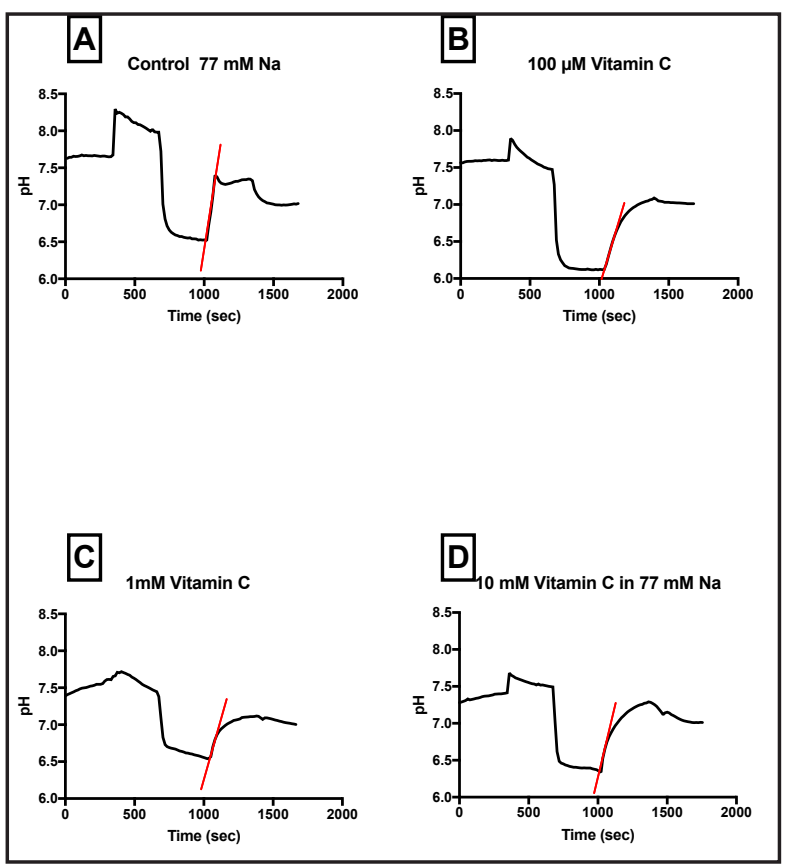

Fig. 4. Tracings showing the recovery rate of intracellular $\mathrm{pH}$ in isolated rat colonic crypts from an acid load in different conditions. Panel A tracing from crypt in control conditions. Panel B tracing from crypt following exposure to $100 \mu \mathrm{M}$ Vitamin C. Panel C tracing from crypt following exposure to $1 \mathrm{mM}$ Vitamin C. Panel D tracing from crypt following exposure to $10 \mathrm{mM}$ Vitamin C. Please note the suppressed Na-dependent $\mathrm{pH}$ recovery following Vitamin $\mathrm{C}$ exposure. 


\section{Cellular Physiology

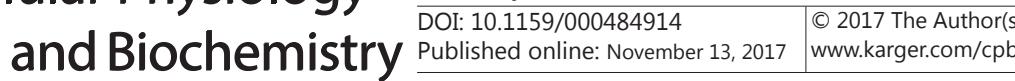

Fig. 5. The effect of SVCT on Vitamin C-dependent $\mathrm{pH}$ modification: Please note the slow recovery rate of $\mathrm{pH}$ with $100 \mu \mathrm{M}$ in 177 $\mathrm{mM} \mathrm{Na}{ }^{+}$concentration in comparison with control experiments of the same $\mathrm{Na}^{+}$concentration. The slower rate of $\mathrm{pH}$ recovery become aberrant with lower doses of Vitamin C dissolved in low $\mathrm{Na}^{+}$concentration solution. $\mathrm{n}=40$.

concentration of Vitamin $\mathrm{C}$ that is dissolved in $77 \mathrm{mM} \mathrm{Na}^{+}$to $10 \mathrm{mM}$; there was no significant difference in the recovery rate of $\mathrm{pH}_{\mathrm{i}}(\Delta \mathrm{pHi} /$ min 0.0190) from that of the control solution of $77 \mathrm{mM} \mathrm{Na}^{+}$. Tracings of $\mathrm{pH}_{\mathrm{i}}$ recovery rates are shown in Fig. 4 , and the summary data shown in Fig. 5.

GLUT Effect On Vitamin $C$-Dependent $p H$ Modification

To study the effect of GLUT on Vitamin C-dependent $\mathrm{pH}_{\mathrm{i}}$ modification, in the first set of this series of experiments we used the same solutions for the first set of experiments in Table 1, but excluding Glucose (117 NaCl) (see Fig. 7). The recovery rate of $\mathrm{pH}_{\mathrm{i}}$ to resting physiological $\mathrm{pH}$ values with $10 \mathrm{mM}$ Vitamin $\mathrm{C}$ in glucosefree solutions $(\Delta \mathrm{pHi} / \mathrm{min} 0.0080)$ was slower with a $p$ value of < 0.0001 in comparison to glucosefree control solutions $(\Delta \mathrm{pHi} / \mathrm{min}$ 0.0133 ). However, there was no significant difference between $10 \mathrm{mM}$ of Vitamin $\mathrm{C}$ dissolved in Glucose solutions and $10 \mathrm{mM}$ Vitamin C dissolved in Glucose-free solutions (See Fig. 7).

Inthesecond setofexperiments we dissolved Phlorizin a known inhibitor of glucose transport (SGLT1 and SGLT2), and Vitamin C in Glucose-free solutions to blunt the activity of GLUT transport. The recovery rate of $\mathrm{pH}_{i}$ with $10 \mathrm{mM}$ Vitamin C plus Phlorizin dissolved in Glucose-free solutions $(\Delta \mathrm{pHi} / \mathrm{min} 0.0081)$ was slower
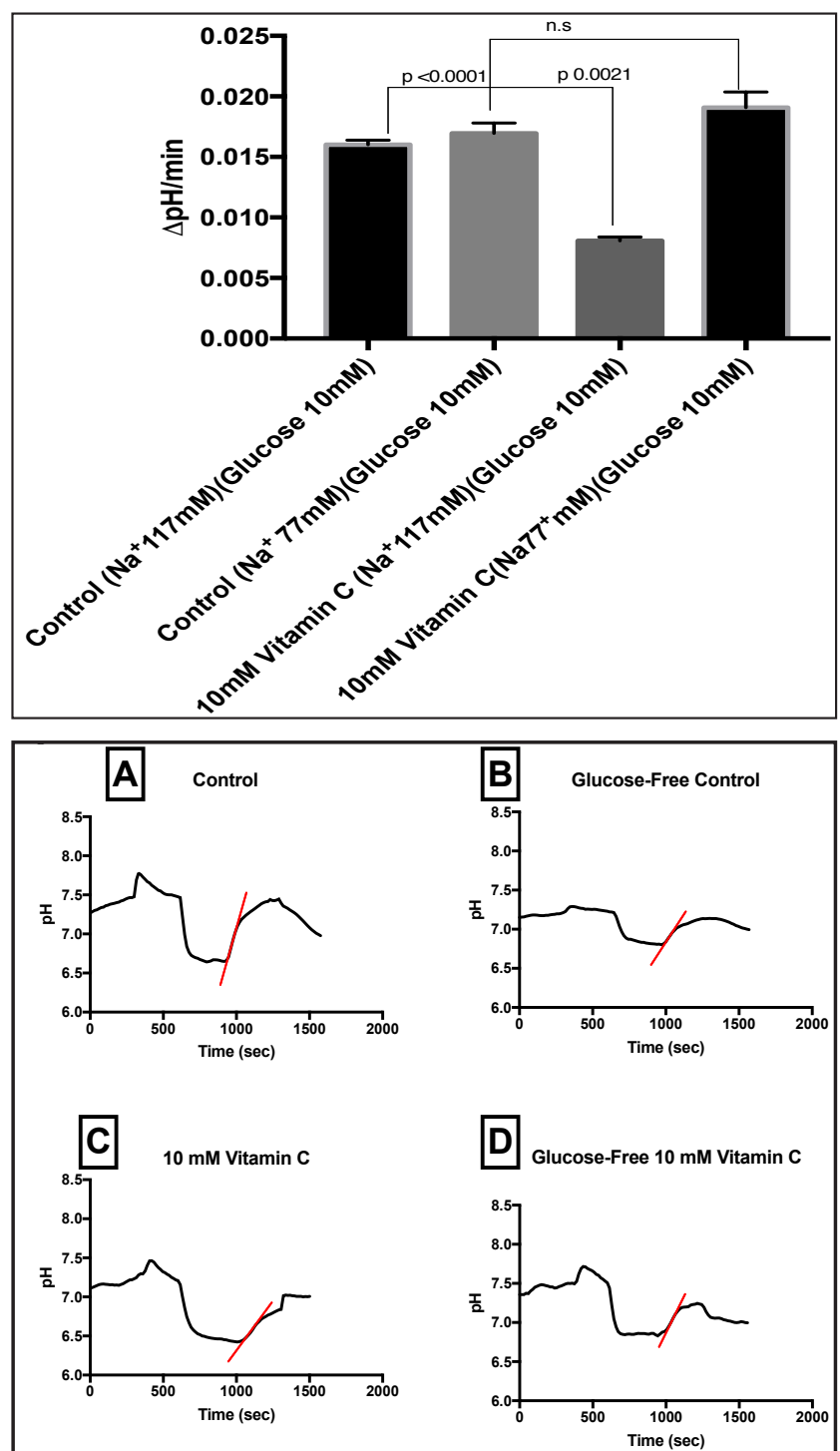

E

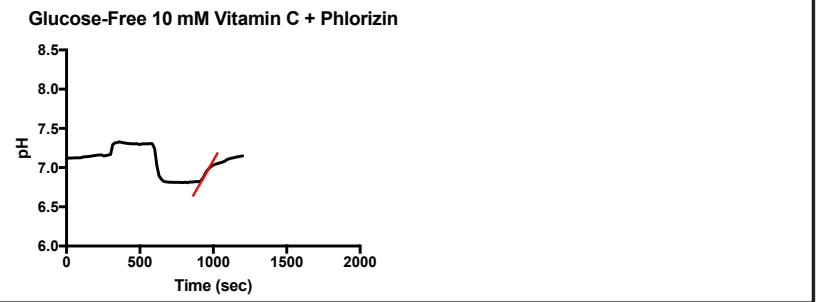

Fig. 6. Tracings showing the recovery rate of intracellular $\mathrm{pH}$ in isolated rat colonic crypts from an acid load in different conditions. Panel A tracing from crypt in control conditions. Panel B tracing from crypt in Glucose-free solutions. C. Panel C tracing from crypt following exposure to $10 \mathrm{mM}$ Vitamin $\mathrm{C}$ in control conditions. Panel D tracing from crypt following exposure to $10 \mathrm{mM}$ Vitamin C in Glucose-free conditions. Panel E tracing from crypt following exposure to $10 \mathrm{mM}$ Vitamin C in Glucose-free condition with added Phlorizin. Please note the suppressed Na-dependent $\mathrm{pH}$ recovery following Vitamin C exposure. 
Fig. 7. GLUT effect on Vitamin C-dependent $\mathrm{pH}$ modification: No significant difference in the recovery rate of crypts perfused with $10 \mathrm{mM}$ Vitamin C in presence or absence of Glucose. Additionally, there was no significance difference after blocking GLUT with Phlorizin in comparison to $10 \mathrm{mM}$ Vitamin $\mathrm{C}$ free of Glucose and Phlorizin. $n=40$.

in comparison with control Glucose-free solutions $(\Delta \mathrm{pHi}$ $/$ min 0.0133 ) with a $p$ value of $<0.0001$. Moreover, there was no significance difference in $\mathrm{pH}_{\mathrm{i}}$ recovery rate when we compared $10 \mathrm{mM}$ Vitamin $\mathrm{C}$ +/- Glucose versus $10 \mathrm{mM}$ Vitamin C plus Phlorizin dissolved in glucose-free solutions. Tracings of $\mathrm{pH}_{\mathrm{i}}$ recovery rates are shown in Fig. 6 with summary data presented in Fig. 7.

The difference between GLUT and SVCT Effects On Vitamin C-Dependent Na-Dependent $\quad p H$ recovery

In this set of studies, we examined the difference in recovery rates between GLUT and SVCT on Vitamin C-dependent $\mathrm{pH}$ modification (See Fig. 9). We compared the rate of $\mathrm{pH}_{\mathrm{i}}$ recovery rates between control experiments that either had no Glucose $(\Delta \mathrm{pHi} / \mathrm{min} 0.0133)$ or had a $\mathrm{Na}^{+}$concentration of $77 \mathrm{mM}$ plus $10 \mathrm{mM}$ Glucose $(\Delta \mathrm{pHi} /$ min 0.0169). We observed that the control experiments that were Glucose free had a slower $\mathrm{pH}_{\mathrm{i}}$ recovery rate than those experiments with 77 $\mathrm{mM} \mathrm{Na} \mathrm{Na}^{+}$concentration plus $10 \mathrm{mM}$ Glucose concentration with a p value of 0.0002 . When we added $10 \mathrm{mM}$ Vitamin $\mathrm{C}$ to the various groups in a separate series
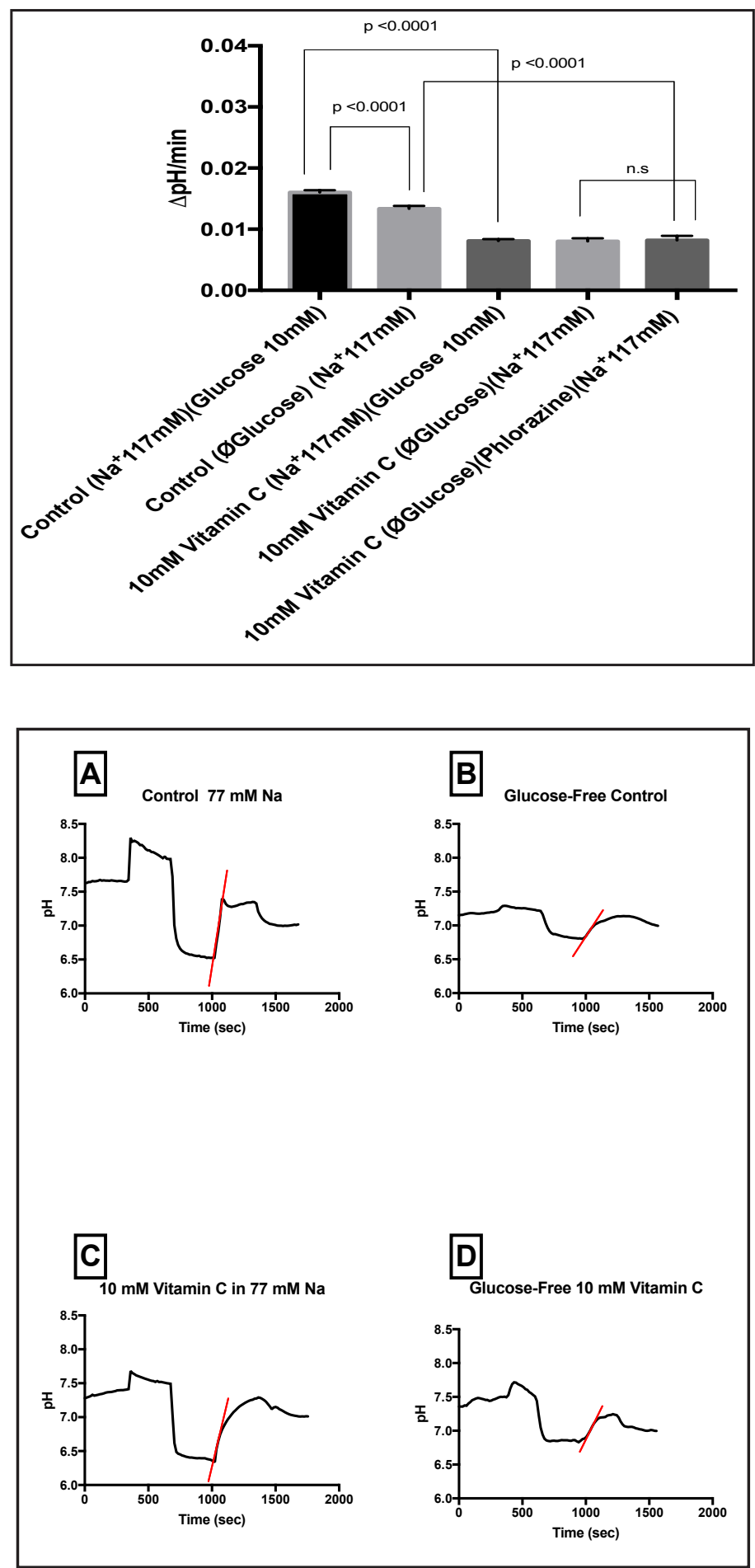

Fig. 8. Tracings showing the recovery rate of intracellular $\mathrm{pH}$ in isolated rat colonic crypts from an acid load in different conditions. Panel A tracing from crypt in control conditions of $77 \mathrm{mM} \mathrm{Na}$. Panel B tracing from crypt in control Glucose Free conditions. Panel $\mathrm{C}$ tracing from crypt following exposure to $10 \mathrm{mM}$ Vitamin C in $77 \mathrm{mM}$ Na. Panel D tracing from crypt following exposure to $10 \mathrm{mM}$ Vitamin $\mathrm{C}$ in Glucose Free conditions. Please note the suppressed Na-dependent $\mathrm{pH}$ recovery following Vitamin $\mathrm{C}$ exposure. 


\section{Cellular Physiology

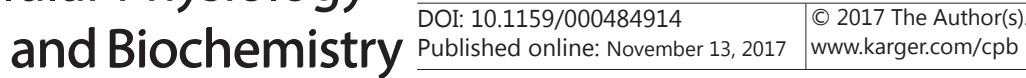 \\ Aldajani et al.: Vitamin C- Dependent Ph Changes in Crypts}

Fig. 9. GLUT and SVCT effect on Vitamin C dependent $\mathrm{pH}$ modification: Please Note that there is a significant difference in $\mathrm{pH}$ recovery rate between the control of $77 \mathrm{mM} \mathrm{Na}^{+}$with that of Glucose-free. When we add $10 \mathrm{mM}$ Vitamin $\mathrm{C}$ to the solutions, the recovery rate of $\mathrm{pH}$ become very slow except with $77 \mathrm{mM} \mathrm{Na}^{+}$concentration that showed a stimulatory effect. $\mathrm{n}=40$.

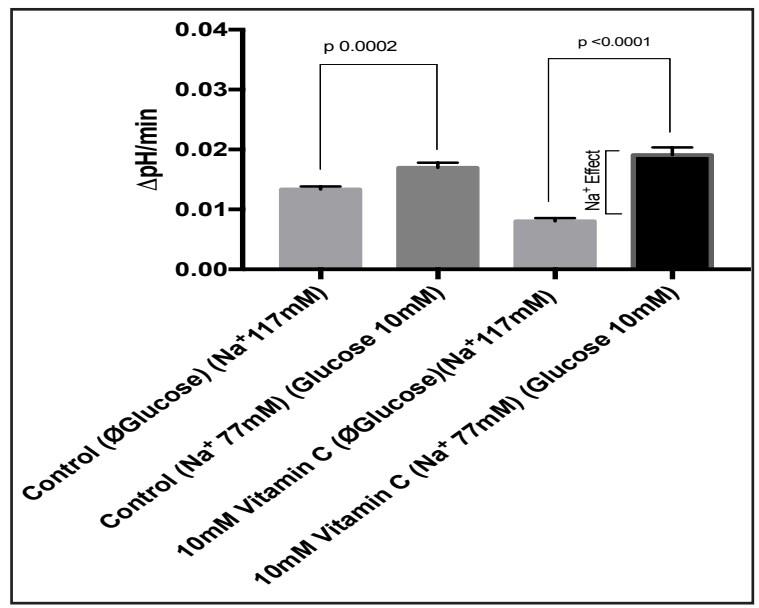

of experiments, we found that the $\mathrm{pH}_{\mathrm{i}}$ recovery rate in the absence of Glucose $(\Delta \mathrm{pHi} / \mathrm{min}$ $0.0080)$ became dramatically slower than that of the $177 \mathrm{mM} \mathrm{Na}^{+}$Glucose-free $(\Delta \mathrm{pHi} / \mathrm{min}$ 0.0133 ) with a $\mathrm{p}$ value of $<0.0001$. Original tracings of $\mathrm{pH}_{\mathrm{i}}$ recovery rates please refer to Fig. 8 with summary data presented in Fig. 9.

\section{Discussion}

Vitamin $\mathrm{C}$ is believed to be an anti-tumorigenic agent in chronic exposure to the colon, but the effect of Vitamin C in the acute condition is controversial and appears to only be antitumorigenic when infused directly into the bloodstream at high concentrations [18]. In retrospective studies published about the benefits of using Vitamin C in cancer treatment there appeared to be some effects $[25,26]$. Later, double-blind trials showed no effect of Vitamin C as a tumoricidal agent [27]. However, in 2008, Chen et al. considered Vitamin C as a cancer therapy from a different perspective from the previous studies mentioned above, notably it was infused directly at high concentrations and was tumor cytotoxic at these high levels [28].

Pandey et al. [29]. established the risk of all cancers in the body being reduced significantly (39\%) when $>113 \mathrm{mg} / \mathrm{d}$ Vitamin $\mathrm{C}$ was consumed, compared to the control group who consumed $<82 \mathrm{mg} / \mathrm{d}$. However, as in all previous studies there were no published data about the effects of Vitamin $\mathrm{C}$ when taken acutely. We, therefore, decided in this paper to concentrate our focus on the acute effect(s) of Vitamin $\mathrm{C}$ on colonic crypts and observe any changes in cellular $\mathrm{pH}$ regulation. These potential acute changes in $\mathrm{pH}_{\mathrm{i}}$ could have a positive effect in regards to carcinogenesis/chemoprevention in the colon according to Vaughan-Jones proposed theory of cancer development [3].

To do so, we noted the changes of intracellular $\mathrm{pH}$ before and after Vitamin $\mathrm{C}$ administration. Our results were obtained using the isolated colonic crypt model from Sprague-Dawley rats. Vitamin C shows a marked effect on the acidity of the crypt cells from intact isolated crypts. Maintaining the $\mathrm{pH}$ acidic intracellularly would inhibit the growth of tumor cells, as tumor cells require the intracellular milieu to be alkaline in order to proliferate.

Our first finding that Vitamin $\mathrm{C}$ appears to affect $\mathrm{pH}_{\mathrm{i}}$ is supported by our experiments on the colonic crypts acidity when superfusing the crypts with solutions mixed with Vitamin C. Adding $10 \mathrm{mM}$ Vitamin $\mathrm{C}$ induced a slower rates of $\mathrm{pH}_{\mathrm{i}}$ recovery $(\Delta \mathrm{pHi} / \mathrm{min} 0.0080)$ in comparison with the control experiment $(\Delta \mathrm{pHi} / \mathrm{min} 0.0160)$ (Fig. 3). With intracellular $\mathrm{pH}$ becoming more acidic, an intracellular milieu has been created that is optimized to prevent tumor cell proliferation.

Furthermore, In the setting of acute Vitamin C administration, we observed in Fig. 3 that exposure to low concentrations $(100 \mu \mathrm{M}$ and $1 \mathrm{mM})$ of Vitamin $\mathrm{C}$ resulted in accelerated recovery rates of $\mathrm{pH}_{\mathrm{i}}(\Delta \mathrm{pHi} / \mathrm{min} 0.0284$ for $100 \mu \mathrm{M}$ Vitamin $\mathrm{C}$ and $\Delta \mathrm{pHi} / \mathrm{min} 0.0203$ for 
Vitamin C $1 \mathrm{mM}$ ) following an acid load which could mean a favorable environment for stimulation of tumor growth, this was reversed (tumor inhibitor effect, slow Na-dependent acid extrusion) with high acute Vitamin C exposure $(10 \mathrm{mM})$. In other words, the effect of Vitamin C on the intracellular pH is concentration-dependent, as observed in Fig. 3 (Vitamin C Concentration Curve), when the colonic crypts were superfused with different concentrations resulting in a biphasic concentration dependent response, low concentrations of Vitamin $\mathrm{C}(100 \mu \mathrm{M}$ and $1 \mathrm{mM})$ maintains high (alkali) $\mathrm{pH}_{\mathrm{i}}$ during the recovery period while high concentration of Vitamin $\mathrm{C}(10 \mathrm{mM})$ maintains low (acidic) $\mathrm{pH}_{\mathrm{i}}$ during recovery period. This observation can be explained by dose dependent modulation of the $\mathrm{Na}^{+}$dependent Vitamin $\mathrm{C}$ transporter (SVCT). This increased activity leads to both increases in $\mathrm{H}^{+}$concentration within the cell as well as increases in intracellular $\mathrm{Na}^{+}$concentration. The higher intracellular $\mathrm{Na}^{+}$concentration prevents NHE from working efficiently due to the increased $\mathrm{Na}^{+}$gradient within the cell. On the contrary, with lower concentrations of Vitamin C, the SVCT is less active which leads to a slower build up in the intracellular $\mathrm{Na}^{+}$concentration. This results in a faster Na-dependent recovery rate.

As we have observed that Vitamin $\mathrm{C}$ transport is dependent on $\mathrm{Na}^{+}$and since we use a $77 \mathrm{mM} \mathrm{Na}^{+}$concentration for our $\mathrm{NH}_{4} \mathrm{Cl}$ prepulse technique different from that of HEPES $(177 \mathrm{mM})$ (Table1), we wanted to eliminate any influence on the recovery rate that may result from this $\mathrm{Na}^{+}$concertation difference between solutions. We performed a new set experiments with HEPES solution that made of $77 \mathrm{mM} \mathrm{Na}^{+}$concentration (Table1), contain or devoid of different Vitamin C concentrations to observe its ability to maintain an acidic intracellular environment of the crypts. There was no significant difference when we compare the recovery rate of pHi between control experiments of $77 \mathrm{mM} \mathrm{Na}^{+}$concentration $(\Delta \mathrm{pHi} / \mathrm{min} 0.0169)$ with control experiments of standard $117 \mathrm{mM} \mathrm{Na}^{+}$concentration $(\Delta \mathrm{pHi} /$ min 0.0160). Comparing the results of the control experiments of $77 \mathrm{mM} \mathrm{Na}^{+}$concentration $(\Delta \mathrm{pHi} / \mathrm{min} 0.0169)$, to those of the $100 \mu \mathrm{M}$ Vitamin $\mathrm{C}$ dissolved in $77 \mathrm{mM} \mathrm{Na}^{+}$solutions $(\Delta \mathrm{pHi} / \mathrm{min} 0.0098)$ we observed a slowing of the rate of $\mathrm{pH}_{\mathrm{i}}$ recovery to the normal resting physiological rate (control conditions) with a $\mathrm{p}$ value of $<0.0001$. A similar slow recovery rate was observed when we increased the concentration of Vitamin C from $100 \mu \mathrm{M}$ to $1 \mathrm{mM}$ $(\Delta \mathrm{pHi} / \mathrm{min} 0.0128)$ with a $\mathrm{p}$ value of 0.0021 . However, when we increased the concentration to $10 \mathrm{mM}(\Delta \mathrm{pHi} / \mathrm{min} 0.0190)$ (a concentration that is used clinically to kill cancer cells), there was no significant difference in the recovery rate of $\mathrm{pH}_{\mathrm{i}}$ from that of the control solution $\left(0 \mathrm{mM}\right.$ Vitamin C). We established that the difference in $\mathrm{Na}^{+}$concentration effects the Vitamin $\mathrm{C}$ dependent intracellular $\mathrm{pH}$ changes, by the rate of $\mathrm{Na}$ dependent proton extrusion, at a (77 $\mathrm{mM}$ ) $\mathrm{Na}^{+}$concentration the opposite effects of Vitamin $\mathrm{C}$ dependent proton extrusion are observed, as seen in Fig. 5 (SVCT Role in Vitamin C Dependent $p H$ modification). This reversal in the recovery rates (Fig. 5) in comparison to $117 \mathrm{mM} \mathrm{Na}^{+}$concentration (Fig. 3) can be explained by the difference in the $\mathrm{Na}^{+}$concentration and the effects on the Vitamin C modulation of SVCT and subsequently on NHE activity, resulting in a modulation in the extrusion rate of $\mathrm{H}^{+}$.

In a recent study published by Maulén et. al. using CaCo- 2 cells they determined that these cells express SVCT 1 selectively on the apical side. Moreover, in the same study they found that SCVT 1 and SVCT 2 have different Km values, SVCT 1 has a lower affinity for Vitamin C (Km $125 \mu \mathrm{M})$ while SVCT 2 has a higher affinity $(\mathrm{Km} 8 \mu \mathrm{M})$ [10]. Their study also finds that there was no transport of Vitamin C across the basolateral surface and that all of the transported Vitamin C is being transported on the apical membrane through SVCT1 [10]. However, in our study, we superfused the intact colonic crypts (isolated from rat colon) in vitro so that all effects were predominantly via changes in basolateral transport. With that being said, and since we did observe a basolateral Vitamin $C$ effect as measured by changes in $\mathrm{pHi}$, these results show that there could be a direct difference in Vitamin C transport from cultured CaCo- 2 cells and intact freshly isolated crypts. In our study Vitamin C could potentially be transported via SVCT2, or it could diffuse through the tight junctions to reach the apical side and interact with SVCT1, or alternatively there could be another protein transporter that has yet to be identified that allows Vitamin C to enter the cells. 
The third outcome of our study is that GLUT transporters have a role to play in Vitamin C transport inside the cell and thereby could manipulate the effect(s) of Vitamin C. As shown in Fig. $710 \mathrm{mM}$ Vitamin $\mathrm{C}$ still maintained an acidic $\mathrm{pH}(\Delta \mathrm{pHi} / \mathrm{min} 0.0080)$ in the intracellular environment after removal of Glucose from the solutions.

When the drug Phlorizin was added to the glucose-free solutions to specifically bind and block SGLT transporters, Vitamin C still was able to change intracellular $\mathrm{pH}(\Delta \mathrm{pHi} / \mathrm{min}$ 0.0081 ) in a similar pattern as previously seen. These results suggest that attenuating GLUT through glucose removal and blocking SGLT with Phlorizin did not modulate the Vitamin C effect on the recovery rate of $\mathrm{pH}$ to the normal physiological value. These results could mean that using Vitamin $\mathrm{C}$ as a therapeutic agent for colon cancer in diabetic patients would still lead to an elevation in intracellular acidity and potentially lead to reduced tumor burden.

Finally, we compared the influences of Glucose and $\mathrm{Na}^{+}$on Vitamin C-dependent proton extrusion rates. We observed that the $\mathrm{pH}_{\mathrm{i}}$ recovery rate of $117 \mathrm{mM} \mathrm{Na}$ is faster when we compared to control experiments of $77 \mathrm{mM} \mathrm{Na}^{+}$concentration that contain $10 \mathrm{mM}$ Glucose $(\Delta \mathrm{pHi} / \mathrm{min} 0.0169)$ with control experiments that have the standard concentration $\mathrm{Na}^{+}$and contain no Glucose $(\Delta \mathrm{pHi} / \mathrm{min} 0.0133) \mathrm{p}$ value 0.0002 . Remarkably, the rate of recovery become more aberrant when we add $10 \mathrm{mM}$ Vitamin $\mathrm{C}$ to the Glucose-free solution $(\Delta \mathrm{pHi} /$ min 0.0080 ) with a p value of $<0.0001$ while there was no significant difference between $77 \mathrm{mM} \mathrm{Na}^{+}$control and $10 \mathrm{mM}$ Vitamin $\mathrm{C}$ with the same $77 \mathrm{mM} \mathrm{Na}^{+}$concentration in the extracellular environment. We believe that $\mathrm{Na}^{+}$concentrations have the major influences on Vitamin C-dependent proton extrusion (Fig. 9) through modulations in Na-Glucose exchange and Na-H Exchange.

In summary, our data for the first time demonstrate the acute effects of Vitamin C on modulating intracellular $\mathrm{pH}$ regulation in isolated colonic crypts. This data is highly suggestive that a positive effect of Vitamin $\mathrm{C}$ as an antitumorigenic agent during chronic exposure can also be achieved in the acute exposure setting.

\section{Disclosure Statement}

There are no competing interests or sponsors that affected this work. All studies are done in compliance with the Yale school of Medicine conflict of interest committee.

\section{Acknowledgements}

This work was supported by the Charles Ohse Grant program from the department of surgery.

\section{References}

$>1$ Siegel R, Desantis C, Jemal A: Colorectal cancer statistics, 2014. CA Cancer J Clin 2014;64:104-117.

-2 Siegel RL, Miller KD, Jemal A: Cancer statistics, 2015. CA Cancer J Clin 2015;65:5-29.

-3 Swietach P, Hulikova A, Vaughan-Jones RD, Harris AL: New insights into the physiological role of carbonic anhydrase ix in tumour ph regulation. Oncogene 2010;29:6509-6521.

4 Swietach P, Vaughan-Jones RD, Harris AL: Regulation of tumor ph and the role of carbonic anhydrase 9. Cancer Metastasis Rev 2007;26:299-310.

5 Davey MW, Montagu Mv, Inzé D, Sanmartin M, Kanellis A, Smirnoff N, Benzie IJJ, Strain JJ, Favell D, Fletcher J: Plant l-ascorbic acid: Chemistry, function, metabolism, bioavailability and effects of processing. J Sci Food Agriculture 2000;80:825-860.

6 Cameron E, Pauling L: Ascorbic acid and the glycosaminoglycans. An orthomolecular approach to cancer and other diseases. Oncology 1973;27:181-192. 


\section{Cellular Physiology Cell Physiol Biochem 2017;44:377-387 \begin{tabular}{l|l|l} 
and Biochemistry & $\begin{array}{l}\text { DOI: 10.1159/000484914 } \\
\text { Published onlIne: November 13, } 2017\end{array}$ & $\begin{array}{l}\text { C) } 2017 \text { The Author(s). Published by S. Karger AG, Basel } \\
\text { www.karger.com/cpb }\end{array}$
\end{tabular}}

Aldajani et al.: Vitamin C- Dependent Ph Changes in Crypts

7 Block G: Vitamin c and cancer prevention: The epidemiologic evidence. Am J Clin Nutr 1991;53:270S-282S.

8 Pollard HB, Levine MA, Eidelman 0, Pollard M: Pharmacological ascorbic acid suppresses syngeneic tumor growth and metastases in hormone-refractory prostate cancer. In vivo 2010;24:249-255.

-9 Chen Q Espey MG, Krishna MC, Mitchell JB, Corpe CP, Buettner GR, Shacter E, Levine M: Pharmacologic ascorbic acid concentrations selectively kill cancer cells: Action as a pro-drug to deliver hydrogen peroxide to tissues. Proc Natl Acad Sci U S A 2005;102:13604-13609.

10 Maulen NP, Henriquez EA, Kempe S, Carcamo JG, Schmid-Kotsas A, Bachem M, Grunert A, Bustamante ME, Nualart F, Vera JC: Up-regulation and polarized expression of the sodium-ascorbic acid transporter svct1 in post-confluent differentiated caco-2 cells. J Biol Chem 2003;278:9035-9041.

11 Huang G, Dragan M, Freeman D, Wilson JX: Activation of catechol-o-methyltransferase in astrocytes stimulates homocysteine synthesis and export to neurons. Glia 2005;51:47-55.

12 Levine M, Rumsey SC, Wang Y, Park J, Kwon O, Amano N: In situ kinetics: An approach to recommended intake of vitamin c. Methods Enzymol 1997;281:425-437.

13 Kc S, Carcamo JM, Golde DW: Vitamin c enters mitochondria via facilitative glucose transporter 1 (glut1) and confers mitochondrial protection against oxidative injury. FASEB J 2005;19:1657-1667.

14 Prasad PD, Wang H, Huang W, Kekuda R, Rajan DP, Leibach FH, Ganapathy V: Human lat1, a subunit of system 1 amino acid transporter: Molecular cloning and transport function. Biochem Biophys Res Commun 1999;255:283-288.

15 Boyer JC, Campbell CE, Sigurdson WJ, Kuo SM: Polarized localization of vitamin c transporters, svct1 and svct2, in epithelial cells. Biochem Bioph Res Commun 2005;334:150-156.

16 Tsukaguchi H, Tokui T, Mackenzie B, Berger UV, Chen XZ, Wang Y, Brubaker RF, Hediger MA: A family of mammalian na+-dependent l-ascorbic acid transporters. Nature 1999;399:70-75.

17 Padayatty SJ, Sun H, Wang Y, Riordan HD, Hewitt SM, Katz A, Wesley RA, Levine M: Vitamin c pharmacokinetics: Implications for oral and intravenous use. Ann Intern Med 2004;140:533-537.

-18 Levine M, Padayatty SJ, Espey MG: Vitamin c: A concentration-function approach yields pharmacology and therapeutic discoveries. Adv Nutr 2011;2:78-88.

19 Cheng SX, Okuda M, Hall AE, Geibel JP, Hebert SC: Expression of calcium-sensing receptor in rat colonic epithelium: Evidence for modulation of fluid secretion. Am J Physiol Gastrointest Liver Physiol 2002;283:G240-250.

20 Cheng SX, Geibel JP, Hebert SC: Extracellular polyamines regulate fluid secretion in rat colonic crypts via the extracellular calcium-sensing receptor. Gastroenterology 2004;126:148-158.

21 Rajendran VM, Geibel J, Binder HJ: Chloride-dependent na-h exchange. A novel mechanism of sodium transport in colonic crypts. J Biol Chem 1995;270:11051-11054.

22 Roginiel AC, Kohut DL, Kaur S, Saleh AM, Weber T, Geibel P, Singh H, Geibel JP: Effect of nsaids on $\mathrm{na}(+) / \mathrm{h}(+)$ exchanger activity in rat colonic crypts. Am J Physiol Cell Physiol 2013;305:C512-518.

23 Kopic S, Corradini S, Sidani S, Murek M, Vardanyan A, Foller M, Ritter M, Geibel JP: Ethanol inhibits gastric acid secretion in rats through increased amp-kinase activity. Cell Physiol Biochem 2010;25:195-202.

-24 Singh SK, Binder HJ, Geibel JP, Boron WF: An apical permeability barrier to nh3/nh4+ in isolated, perfused colonic crypts. Proc Natl Acad Sci U S A 1995;92:11573-11577.

-25 Cameron E, Pauling L: Supplemental ascorbate in the supportive treatment of cancer: Prolongation of survival times in terminal human cancer. Proc Natl Acad Sci U S A 1976;73:3685-3689.

-26 Cameron E, Pauling L: Supplemental ascorbate in the supportive treatment of cancer: Reevaluation of prolongation of survival times in terminal human cancer. Proc Natl Acad Sci U S A 1978;75:4538-4542.

27 Moertel CG, Fleming TR, Creagan ET, Rubin J, O’Connell MJ, Ames MM: High-dose vitamin c versus placebo in the treatment of patients with advanced cancer who have had no prior chemotherapy. A randomized double-blind comparison. N Engl J Med 1985;312:137-141.

28 Chen Q Espey MG, Sun AY, Pooput C, Kirk KL, Krishna MC, Khosh DB, Drisko J, Levine M: Pharmacologic doses of ascorbate act as a prooxidant and decrease growth of aggressive tumor xenografts in mice. Proc Natl Acad Sci U S A 2008;105:11105-11109.

29 Pandey DK, Shekelle R, Selwyn BJ, Tangney C, Stamler J: Dietary vitamin c and beta-carotene and risk of death in middle-aged men. The western electric study. Am J Epidemiol 1995;142:1269-1278. 